\title{
Development and Utilization of Art Educational Resources Based on Carrying forward the National Culture
}

\author{
Xu Min \\ Xiamen Institute of Software Technology, Xiamen China
}

\begin{abstract}
Keywords: carry forward; national culture; art educational resources of colleges and universities; development and Utilization

Abstract. The development and utilization of art educational resources of colleges and universities is supposed to carry forward the national culture, which not only serves as an important carrier for the reinforcement of the cohesion of the people, but also meets the needs of the achievement of the great rejuvenation of the Chinese nation. The national culture shall be effectively adopted in the course of art education. Rich in content, the national culture can be presented in various artistic forms. Promoting national culture in essence means actively improving the form and content of art education in colleges and colleges and universities. It has become a priority regarding the management of universities and colleges on how to develop and utilize the art educational resources to carry forward the national culture. As an integral part of quality education, art education can boost the comprehensive quality of the students. Therefore, it's necessary to make the best of the national culture, and make it serve as a guide. Besides, it's required to inherit and promote the national culture, maintaining the development and utilization of art educational resources of colleges and universities. The development of national culture in the new era will also enable the students to have a deeper understanding of the spiritual value of the national culture, playing an important role in helping students to foster a correct outlook on the world, life and values. This thesis analyzes the cases on the development and utilization of art educational resources of colleges and universities on the basis of promoting the national culture.
\end{abstract}

\section{Introduction}

As the constant development of economic globalization, the world cultural integration is increasingly possible. It has become a focus concerning national development on how to more effectively carry forward the national culture amid development of diversity. The promotion of national culture is beneficial for the preservation of the traditions of the Chinese nation, ensuring the continuity of the traditional Chinese culture. Art education of colleges and universities is an important carrier for carrying forward the national culture. It helps to enrich the thinking of the students. Carrying out art education in colleges and universities shall be compatible with carrying forward the national culture, and colleges and universities are expected to develop and utilize their own art educational resources by applying the national culture. This will help to improve the current situation of the national culture. Excellent national culture play a positive role in cultivating artistic talents. Colleges and universities are supposed to pursue artistic integration in the course of carrying out cultural education and foster more professional talents, so as to better inherit and develop the national culture.

\section{The Importance of Carrying forward the National Culture in the course of Developing and Utilizing Art Educational Resources of Colleges and Universities}

Giving priority to national culture embodies the improvement and awaking of subject consciousness. Highlighting subject consciousness in art education of colleges and universities helps to enhance national cohesion, which is a basic requirement for the great rejuvenation of the Chinese nation. The development of a nation is closely related to cultural innovation. It' $\mathrm{s}$ necessary to constantly apply and develop the national culture. As national subject consciousness is absent from the aesthetic consciousness in this new era, art education in colleges and universities only attaches 
importance to artistic teaching, discouraging students from getting more profound understandings of art. Superficial forms of art are not helpful for the inheritance of the national culture. Failure in art education will make people have a more unilateral perspective toward our national culture. Lack of basic artistic skills and accomplishments will have a severe negative effect on the improvement of comprehensive quality of the students. The development and utilization of art education in colleges and universities can create a good learning environment for students, enabling them to have a full understanding of the effects and functions of the national culture. It' $s$ necessary to improve the basic artistic accomplishment of students and strengthen their patriotic feelings. National culture shall accept constant innovation in the new era so as to meet the needs of development of students. Personalized life will have a relatively severe negative effect on the inheritance and development of national culture. Students affected by this cultural environment can' t have their ideology and value orientation improved, and apparently lack national aesthetic consciousness. Special attention should be paid by colleges and universities to this kind of cultural phenomenon and environment during the development and utilization of art educational resources. Reflection on the current cultural phenomenon ensures the inheritance and continuity of the spiritual values of the national culture. The importance of national culture shall be emphasized during carrying out art education in colleges and universities and national culture shall be fully applied in the course of developing and utilizing the art educational resources. Continuing the life of national culture plays a significant role in realizing the inner charm of art. Developing and utilizing art educational resources enables students to understand the essence of the national culture and increase their national confidence, thus encouraging them to take the heavy responsibility of inheriting the national culture. Colleges and universities shall guide the students to learn own national culture, and seek the origin of our national culture by making use of the art educational resources, gradually expanding the effects of the national culture on the social development in the new era. Recognizing the change of our national culture and developing and utilizing the art educational resources with a perspective of diversification enable students to have a deeper understanding of our national culture. Besides, this is also an important method to enrich our national culture and promote art education of colleges and universities.

\section{Feasibility of Carrying forward the National Culture in the course of Developing and Utilizing Art educational resources in Colleges and Universities}

Rich Art Resources. China boasts a long history, and it has formed a national culture with distinctive characteristics for thousands of years. The inner value of our national culture has attracted a growing number of students to study it. Art education in colleges and universities helps students to have a full understanding of the history, and the content and environment of our national culture and make them realize the evolution of our national development. This kind of study will arouse students' interests and help them to study in accordance with the cultural features of different regions. The rich content of our national culture is the prerequisite of the development and utilization of art educational resources of colleges and universities.

Diversity of the Forms of Art. Different nations vary obviously from each other regarding lifestyles, living environments and other aspects. Unique artistic forms are the result of different social development stages and natural conditions. Learning national culture helps to improve the understanding of the intangible cultural heritage, and encourages students to pay more attention to humanistic spirit in the course of art education. The classic art and culture contribute to the inheritance of the philosophy and civilization. The continuity of the national culture requires the development and utilization of art educational resources of colleges and universities, which enables students to fully obtain the national culture. The development and utilization of art educational resources of colleges and universities can make up the shortfalls emerged when carrying forward the national culture. It can make people have a better understanding of our national culture and ensure the proper continuity of our national culture, making the national culture an integral part of our ideology. 


\section{Carrying forward the National Culture Is the Responsibility of the Colleges and Universities in Developing the Contemporary Art Education}

The Contemporary Values of the National Culture. Art education shall be supported by profound inner values, which is the key point of contemporary art development. The national culture serves as an essential medium in carrying out art education of all forms. During the practical art education, the values of people shall be presented and the importance of people in art development shall be highlighted. Art education is a must in the dissemination of the national culture. Especially for today where diverse cultures develop together, new requirements are asked for carrying out art education in colleges and universities. Carrying out art education in colleges and universities is a manifestation of promoting quality education, and serves as a carrier for inheriting and creating the national culture, playing an essential role in enriching the art and culture. The national culture can inject new vitality to art education in colleges and universities. Through developing and utilizing the art educational resources, colleges and universities can foster more professional artistic talents as it' $s$ geared to the development of socialist civilization. Intensifying art education in colleges and universities helps to promote the aesthetic value and cultural appreciation of students, and build and improve their fundamental personality. Through carrying forward the national culture, colleges and universities can help promote the learning ability of students, making them well adapted to the social development. As the society keeps developing, art education of colleges and universities plays a significant role in carrying forward the national culture. To make students better understand our national culture has gradually become a priority of art education in colleges and universities.

Carrying forward the National Culture Is an Important Mission of Colleges and universities during Art Education. The core value of our national culture boasts distinctive charms. Over several thousand years of development, the national culture has shown more harmony and inclusiveness. As the main body of our national culture, harmony and inclusiveness play a significant role in forming the socialist core values. During the development and utilization of art educational resources, colleges and universities are supposed to keep carrying forward the national culture, shoulder their historical mission, and integrate art culture with social development, promoting sustained development of our society. Transformation and development are needed in this new era and disparity in mentality will leads to various contradictions. Therefore, the difference in cultural values must be guided by the colleges and universities through the establishment of core value system. Carrying out art education helps to improve and coordinate interest mechanism, and promote our national culture in a harmonious and inclusive way. This will ease social contradictions, and promote the emergence of a new look of mutual assistance. Carrying out art education in colleges and universities will create a good environment for promoting our national culture, achieve effective communication between different classes and promote a harmonious development of our society. Art education of colleges and universities serves as a carrier for the inheritance and development of the national culture, the core values of which must be born in mind at all time.

Choosing the Proper Way to Carry forward the National Culture. During carrying out art education, colleges and universities must ensure that students can improve their artistic accomplishments in the cognitive level and adopt a right attitude towards the problems arising in our society. Colleges and universities are supposed to give high priority to the national culture, and give a detailed analysis to the inner values of it. Integrated with art education, the national culture can take on a new look in this new era. Colleges and universities must stick to their own cultural value, highlight the cultural strength, and improve the cultural accomplishments of students. More efforts on the study of the national culture will help to promote a right understanding of the core values of it. Only in this way, can the students better inherit and develop our national culture, and better distinguish different cultures amid the social changes. In the pursuit of the supreme value of the national culture, attention must be paid to the research of the modern philosophy and a holistic perspective must be adopted. Students are supposed to understand the inner values of the national culture under the modern scientific philosophy, and distinguish the modern culture from the 
traditional culture. Besides, they are expected to take a positive attitude towards the development of the national culture, and be able to interpret it with the modern philosophy.

Talent Cultivation Model of Multifold Arts. The national culture in different regions boasts distinctive characteristics, which is to be highlighted during the development and utilization of art educational resources of colleges and universities. Only in this way, can our national cultures be better carried forward. Artistic talents are the driving force for carrying forward the national culture, therefore colleges and universities must attach importance to the cultivation of professional artistic talents and coordinate the school resources with after-school activities, enabling students to fully realize the uniqueness and difference of the national culture in various regions. Art education of colleges and universities is expected to have an effect on the aesthetic standards of the students and more national cultures should be adopted during the art education of colleges and universities. Limitation of the traditional culture must be broken. Art education shall keep up with the times, which means manifold teaching resources should be applied for the artistic cultivation of students. The improvement of the learning ability of students is important for carrying forward the national culture as well as fostering the artistic accomplishments of themselves. Art education in colleges and universities and the national culture are expected to have a guiding function for the cultivation of professional artistic talents.

\section{Measures for the Development and Utilization of Art educational resources of Colleges and Universities Aimed at Carrying forward the national culture}

Promoting the Integration of Various Subjects. Integrated with classic poems and articles, teaching forms like calligraphy, reading and writing can be strengthened in the course of art education. Subjects like Morality and Life, Society, Music, and Physical Education are possessed of resources to be developed and integrated. Integration of classic poems and articles makes the subjects better carried out. Emphasizing the classic culture helps to create a scholarly campus. Top four cultural galleries are to be built, classic proverbs of ancient celebrities are to be posted on the walls around the school, and the magnificent spraying painting of The Rock Bamboo created by Zheng Banqiao is to be presented to reveal life philosophy to the teachers and students. The publication window and the blackboard of the classrooms should be used to post pictures and poems. Classic paintings, calligraphies and famous proverbs are to be presented in the classrooms and offices. Melodious classic music is to be played in the broadcasting station. A scholarly campus makes the students to bath in an environment of classic poems and articles.

Establishing Activity Platforms and Multifold Estimating Systems. To create a platform for teachers and students to communicate and exchange ideas, colleges and universities are supposed to carry out colorful activities on chanting classics. Those activities are open to all the students, and involve whole participation and ask for different requirements. The chanting activities are to be carried out in class, grade or school. The forms involved are diverse. Firstly, competitions are to be carried out to evoke enthusiasm of students. The competitions are rich both in content and form, including versifying, poem solitaire, You Ask Me Answer, antiphonal singing contests, comedy, comic, allegro, mime, poetry creation, speech, calligraphy, poetry with painting, animation design and so on. All these make students get close to classic poems and articles with pleasure.

Secondly, chanting poems is another priority. Leisure time before class should be fully used to carry out chanting activities, ensuring that poems are read and chanted frequently. Thirdly, poetry clubs are to be created, ensuring the students can practice what they learn. Students interested in poems and articles are expected to be enrolled into the poetry clubs and be organized by professional teachers to carry out activities involving versifying and painting, classic poems rewriting, application, and appreciation as well as ancient poems creation. Students are encouraged to publish their own poems. Fourthly, activity results are supposed to be presented to test effects. The presentation activity concerning chanting results of classic poems is to be carried out each term to test chanting effects of students in the form of playing, singing, chanting, reciting, calligraphy and painting. The classic poems and articles are simple in form and rich in content. Considering students may lose their interest 
in chanting these poems and articles with a monotonous form, colleges and universities can solve this problem through multifold evaluation and stimulation methods, which enable students to fully enjoy the pleasure and outcome of poem chanting.

Strengthening Calligraphy among Teachers, Making Every Teacher Become a Calligraphy Teacher. As the saying goes, "To be a blacksmith, you need to be tough yourself." To improve the handwriting of the students, the teachers themselves must have a smooth handwriting first. Only in this way, can they set a good example for the students and better guide the handwriting of the students Three forms of handwriting are to be strengthened among teachers including handwritings by chalk, by pen and by brush. Teachers should help each other regarding handwriting and famous calligraphers should be employed to guide the teachers on handwriting. Teachers are supposed to practice handwriting in specific time with specific aims, and calligraphy contests should be carried out among teachers at regular intervals. The aim to make every teacher become a calligraphy teacher can basically be achieved if the teachers are interested in practicing handwriting and see a big improvement in their calligraphy.

Giving High Priority to Handwriting Education in Subject Teaching. The principle of giving prior priority to handwriting class and emphasizing other subjects should be advocated. Recognizing characters and writing characters in Chinese class are good ways for calligraphy education. Teachers of Science, Morality and Society who are equipped with a smooth calligraphy and be strict to the handwritings of students are actually giving calligraphy education to students. In the course of reading refined articles, the students' spiritual world will be affected imperceptibly by the distinctive charms of calligraphy. This evokes students' interest in learning calligraphy. If all students are able to present a good handwriting, their ability to feel, to explore, to comprehend and to present will be improved together. They will recognize the charm of the Chinese character and the profound essence of it as the carrier of the Chinese culture. As a result, their moral sentiments will be elevated.

The Improvement of the Comprehensive Quality of Students. Obvious improvements have been achieved in the memory, comprehension ability, expression ability and writing ability of students. Average students can recite 300 poems, and some even can recite as many as 600 poems. All the students can recite the classic Chinese poems and articles, and some have started to create their own poems inspired by the poems they have read and recited.

Intensifying and Improving Management . Art education is an effective way to carry out quality education for students, and colleges and universities are supposed to attach great importance to it. Colleges and universities should take specific measures to ensure that students can get comprehensive development and have their own strong points. Colleges and universities are expected to make greater efforts to strengthen management, make clear their measures and promote comprehensive improvement. In recent years, constant development has been achieved in the art education of colleges and universities and adhering to the spirits of the superior, colleges and universities have gradually established and improved their management and operation systems. The medium and long term plans and annual plan regarding art education of colleges and universities have been made. Systems concerning enrollment, study, social activities and contest have also been formulated. To effectively boost art education characterized with national cultures, colleges and universities should build the leading groups on art education with the headmaster as the group leader and supported by a sub-leader and a general art tutor. To strengthen the leadership on art education, the sub-leader is supposed to serve as the principal of the special art program, in charge of the enrollment and daily management. By doing this, the management concerning art education has been improved. Art education is supported by 5 elements, namely specific teachers, perfect plans, thorough contents, plenty time and broad space.

Implementing the Measures, Ensuring the Development of Special Programs. The traditional art is a mirror of the ideology, the culture and the philosophy of a nation. The traditional Chinese art has been affected by Confucian culture, Taoist culture and Buddhist culture during the long history, and it has become a distinctive one in the world through mutual absorption and integration with other 
cultural forms. The culture boasts rich contents, including language, thinking, belief, custom, legal systems, tool and technology, art and etiquette. In a word, culture is defined as the fortune created by men through physical or mental efforts with an aim to satisfy their material and spiritual life. Colleges and universities should establish a stable faculty with strong responsibility and excellent professional skills. Colleges and universities should employ art teachers with rich experience from other schools in order to ensure education equality and enrich the teaching staff. For many years, colleges and universities have made sure that enough funds were spent on the salary of art teachers from other schools and art-related activities, costumes and instruments. It' s necessary to make students realize the unique role of the national and folk arts in the historical development, and essential to guide them to preserve and inherit the national culture. Inheritance ensures the continuity of history, and is the abbreviation of the essence and manifestation of the nation. Besides, inheritance also serves as the foundation and the soul of human development. The Chinese folk art in ancient times was inherited with family as a unit. During the teaching process, teachers can exploit and make full use of the national and folk art resources in different regions. They should organize students to visit folk artisans and people with rich knowledge of other traditional cultures, and record related information. Students can learn to draw and make some national and folk arts. Art education must meet the needs of the students. No matter whether it' $\mathrm{s}$ a folk culture which has long been neglected, or ancient culture which is far from the modern society, students can get a new understanding of them through classroom learning. Students can obtain a new interpretation with a cultural perspective, which will become the way of thinking of students and therefore change their lives.

\section{Conclusion}

Art educational resources of colleges and universities should be developed and utilized on the basis of carrying out the national culture. As an important reflection of the development of the nation and the improvement of people' $\mathrm{s}$ lives, the national culture is characterized with diversity and complexity. Colleges and universities are supposed to make national culture a part of the daily teaching system, and keep enriching the content of art education. Besides, colleges and universities are expected to shoulder the heavy responsibility of inheriting and carrying forward the national culture, positively innovate and practice the national culture and fulfill socialist core values. Art educational resources of colleges and universities can boost the healthy development of the social civilization, enabling students to properly recognize the national culture, so great attention should be paid to the development and utilization of them. It' $s$ necessary to strengthen the national spirit and cultural accomplishments of students so as to ensure the improvement of the morality of students. This is also a priority of art education of colleges and universities in the new era. National culture is a manifestation of the Chinese tradition, and the resilience and unique charm constitute the main body of it. The soft strength contained in the national culture will affect the daily lives of people, which shows the universality of the national culture. Colleges and universities are supposed to play a role in carrying forward the national culture, so they should have a proper understanding of the national culture, integrate art education with the national culture, and promote the development and utilization of resources. This will ensure the effective continuity of the cultures. Carrying forward the national culture amid diverse cultures is a priority for colleges and universities to effectively develop and utilize the art educational resources in the new era.

\section{References}

[1]Lin Guilong. Pottery Culture Enters the Campus, Promoting Development with Distinctive Features - - Reflection and Practice of Huyang Primary School of Shanghang County on Building a School with Characteristics[J]. When the Chinese Publication: Headmaster, 2015(5):74-75.

[2]Zhao Lingang. Pottery Culture Enters the Campus, Promoting Development with Distinctive Features - - Reflection and Practice of Huyang Primary School of Shanghang County of Fujian 
Province on Building a School with Characteristics[J]. When the Chinese Publication: Headmaster, 2015(Z1):32-33.

[3]Zhang Wensheng. Carrying forward the Academic Culture, Building a School with Characteristics - - Reflection and Practice of Yangshan Middle School on Building a School with Characteristics[J]. Novo Times, 2014(1):66-69.

[4]Lin Xiaohong. Promote Leapfrog in More Areas, Create Characteristics - - Experience on Building a School with Characteristics of Primary School of Shanghang County[J]. Fujian Education, 2013(48):26-27.

[5]Wang Jianghua. Research on Issues Arising from the Development and Utilization of Education Resources in the National Culture of Schools in Minorities-Case Study of Bai Nationality of Zhou City of Dali of Yunnan Province[D]. Southwest University, 2010.

[6]Liu Shuiqing. Establishing Galleries with Characteristics by Making Use of the National Culture of the Northwest Part of Guilin —-A Brief Analysis of the Galleries of Hedi College[J]. Art and Technology, 2012(5):226-227. 